\title{
Oral treatment with etoposide in small cell lung cancer - dilemmas and solutions
}

\author{
Renata Rezonja², Lea Knez³ ${ }^{3}$ Tanja Cufer ${ }^{3}$, Ales Mrhar ${ }^{1}$ \\ ${ }^{1}$ Faculty of Pharmacy, University of Ljubljana, Ljubljana, Slovenia \\ ${ }^{2}$ Krka, d.d., Novo mesto, Slovenia \\ ${ }^{3}$ University Clinic Golnik, Golnik, Slovenia \\ Radiol Oncol 2013; 47(1): 1-13.
}

Received 14 September 2012

Accepted 8 November 2012

Correspondence to: Prof Aleš Mrhar, PhD, Faculty of Pharmacy, University of Ljubljana, Aškerčeva 7, SI-1000 Ljubljana, Slovenia. Phone: +386 14769 541; Fax: +386 14258 031; E-mail: ales.mrhar@ffa.uni-lj.si

Disclosure: No potential conflicts of interests were disclosed.

Background. Ełoposide is a chemotherapeutic agent, widely used for the treatment of various malignancies, including small cell lung cancer (SCLC), an aggressive disease with poor prognosis. Oral etoposide administration exhibits advantages for the quality of life of the patient as well as economic benefits. However, widespread use of oral etoposide is limited by incomplete and variable bioavailability. Variability in bioavailability was observed both within and between patients. This suggests that some patients may experience suboptimal tumor cytotoxicity, whereas other patients may be at risk for excess toxicity.

Conclusions. The article highlights dilemmas as well as solutions regarding oral treatment with etoposide by presenting and analyzing relevant literature data. Numerous studies have shown that bioavailability of etoposide is influenced by genetic, physiological and environmental factors. Several strategies were explored to improve bioavailability and to reduce pharmacokinetic variability of oral etoposide, including desired and undesired drug interactions (e.g. with ketoconazole), development of suitable drug delivery systems, use of more water-soluble prodrug of etoposide, and influence on gastric emptying. In addition to genotype-based dose administration, etoposide is suitable for pharmacokinetically guided dosing, which enables dose adjustments in individual patient.

Further, it is established that oral and intravenous schedules of etoposide in SCLC patients do not result in significant differences in treatment outcome, while results of toxicity are inconclusive. To conclude, the main message of the article is that better prediction of the pharmacokinetics of oral etoposide may encourage its wider use in routine clinical practice.

Key words: oral etoposide; bioavailability; pharmacokinetic variability; small cell lung cancer

\section{Introduction}

Etoposide is a topoisomerase II inhibiting anticancer drug, derived from podophyllotoxin. It has significant therapeutic activity in childhood leukemia, testicular tumors, Hodgkin's disease, large cell lymphomas and small cell lung cancer (SCLC). ${ }^{1}$ In combined therapy with platinum compound (cisplatin or carboplatin), etoposide is used as a first-line therapy for SCLC, an aggressive disease with poor prognosis, which represents roughly $20 \%(15-25 \%)$ of all lung cancers. ${ }^{2-7}$ With etoposide and cisplatin or carboplatin combination an overall response rate of approximately $75 \%$ can be anticipated. Radiation therapy to the thorax in addition to platinum/etoposide chemotherapy is associated with a small, but significant improvement in local control and overall survival in limited-stage disease. ${ }^{8}$ Progress in the management of SCLC has been modest in recent years as initial results of cisplatinum plus irinotecan showed improved survival. However these results were not confirmed in subsequent trials and cisplatinum/ etoposide chemotherapy remains cornerstone of 
treatment for patients with SCLC. ${ }^{9,10}$ In addition, some major contribution over the last 20 years has come also from radiotherapy. ${ }^{11}$

The mode of action of etoposide involves inhibition of topoisomerase II, a nuclear enzyme that is necessary for swivelling and relaxation of deoxyribonucleic acid (DNA) during replication and transcription. Etoposide inhibits the ability of topoisomerase II to relegate cleaved nucleic acid molecules by the formation and stabilisation of a topoisomerase II-etoposide-DNA ternary complex and thus increases topoisomerase II-mediated DNA breakage. The covalent topoisomerase IIcleaved DNA complex is normally a short-lived intermediate in the reaction and is tolerated by the cell. However, at high concentrations it has cytotoxic effects, probably due to impaired DNA repair, leading to apoptosis. ${ }^{12,13}$

The activity of etoposide is dose- and schedule-dependent, and etoposide efficacy might be improved markedly with repeated drug administration. ${ }^{12-17}$ Etoposide directly interacts with the ATP-bound enzyme monomer in such a way that each molecule of etoposide stabilizes only a singlestranded break. Depending on the dose of etoposide, single-stranded or double-stranded DNA breaks are generated. ${ }^{13,14}$ Furthermore, the inhibition of topoisomerase II by etoposide is reversible and discontinuation of ternary complex allows quick DNA repair and diminishes the cytotoxicity of the drug. Thus, prolonged exposure to etoposide could increase the anticancer activity of the drug. ${ }^{12}$ Moreover, topoisomerase II is significantly expressed only in dividing cells during S and G2 phases of the cell cycle. Chronic scheduling maximizes the likelihood of exposing malignant cells to etoposide during sensitive periods of the cell cycle. ${ }^{14}$ However, myelosupression as the dose-limiting toxicity should be taken into account when planning the chemotherapy regimen. ${ }^{14}$ The chemotherapy treatment is therefore given in cycles, attacking cancer cells at their most sensitive periods, and allowing normal body cells time to recover.

A wide range of doses and schedules of etoposide are in use, depending on the treated disease. In patients with solid tumors, including SCLC, lower doses, such as $50-100 \mathrm{mg} / \mathrm{m}^{2} /$ day over 3-5 days are suggested by some authors, while other authors suggest prolonged schedule as superior. ${ }^{18-20}$ In most regimens etoposide is administered in cycles, which are usually repeated every 3-4 weeks. ${ }^{1,21}$

Etoposide is commercially available in both intravenous and oral formulations. The oral formulation exhibits advantages for the patient as well as economic benefit compared with the intravenous one. The work from Liu and coworkers has indicated that $89 \%$ of incurable cancer patients preferred oral over intravenous chemotherapy, predominantly because of the convenience of administration, problems with intravenous access or needles, and a better chemotherapy-taking environment (outside of the clinic). ${ }^{22}$ In general, the quality of life of patients receiving palliative chemotherapy for advanced cancer was significantly poorer in patients treated at hospital compared with those treated at home. ${ }^{23}$ Most importantly, the oral formulation may provide an attractive alternative for patients who are unable to or have difficulty making the necessary and frequent visits to receive intravenous therapy. ${ }^{24}$ In comparison with intravenous infusion, oral administration of etoposide represents a significant cost saving for hospital and health insurance. Results of an economic analysis, which was conducted within a randomised multicentre study comparing the use of intravenous etoposide versus oral etoposide treatment in SCLC patients, reported a $17 \%$ savings for patients receiving the oral regimen. The following costs were examined: antineoplastic drugs, intravenous fluids, supplies used for chemotherapy administration, and chemotherapy administration procedure fees. ${ }^{25}$ Furthermore, the introduction of oral etoposide into combination chemotherapy regimens may shorten the hospitalization period and thus reduce non-drug related treatment costs as well. ${ }^{26}$

However, despite the numerous advantages of oral therapy, the intravenous formulation has been used more extensively. ${ }^{24}$ The main drawback of oral etoposide is its incomplete and variable bioavailability. ${ }^{27}$ Approximately 50\% (30-97\%) of the oral dose is bioavailable when compared with the intravenous route. ${ }^{26-29}$ This means that the area under the curve (AUC) of a given oral dose is approximately $50 \%$ of what would be achieved after an intravenous dose. Additionally, variability in bioavailability was observed both within and between patients. Hande et al. ${ }^{30}$ reported a mean etoposide bioavailability at a dose of $50 \mathrm{mg} 64.6 \%$, with intrapatient coefficient of variation (CV) $22.6 \%$ and interpatient CV $34.8 \%$. A large CV suggests that some patients are receiving inadequate drug exposure, resulting in suboptimal tumor cytotoxicity, whereas others may be at risk for excess toxicity. ${ }^{30}$ This is particularly important when using drugs with a narrow therapeutic window, like etoposide. ${ }^{31}$ Additionally, a linear pharmacokinetic behaviour of oral etoposide was shown only for doses up to $200 \mathrm{mg}$. ${ }^{32}$ In higher doses, the percentage of 
absorbed etoposide may decrease while the CV in oral etoposide bioavailability may even increase. ${ }^{29}$

The absorption of etoposide is likely to depend on a number of interacting factors, the identification of which may be difficult. The improvement in the absorption of etoposide and the reduction in its variability, remain important goals to facilitate the clinical use of oral etoposide. ${ }^{27}$

This review focuses on the impact of various factors influencing bioavailability of etoposide, provides possibilities for its improvement and suggestions for treatment optimisation to ensure comparable pharmacokinetic parameters of oral and intravenous application. The review is restricted to treatment with etoposide in SCLC patients, for which etoposide-platinum doublet still represents the most effective standard therapy.

\section{Bioavailability of oral etoposide}

Bioavailability is the extent to which an administered drug enters the systemic circulation. It is defined by the AUC of the dose delivered by oral administration divided by the AUC of the intravenous application of the same dose. AUC of etoposide correlates with safety and efficacy as well as overall survival of patients with SCLC. ${ }^{33,34}$ Oral administration may increase AUC variability because the drug must undergo additional processes such as being transported across the intestine, passing through the liver, and entering the systemic plasma circulation. ${ }^{30}$ Those are pharmacokinetic processes called absorption, first-pass metabolism and elimination prior entering the systemic circulation. ${ }^{35}$ Variation in the pharmacokinetics of a drug in a patient population is the net result of many complex interactions between genetic, physiological and environmental factors. ${ }^{36}$ The impact of these factors on pharmacokinetic processes and consequently AUC and bioavailability is described in some details in the following sections.

\section{Genetic factors}

Genetic characteristics of metabolizing enzymes and transporters may influence drug blood level. Inherited differences in enzymes and transporters are known examples of pharmacogenetic variability. These factors may lead to inter-individual variation. $^{37}$

Etoposide is a substrate of the efflux membrane transporters (ABC transporters) and metabolizing enzymes, which are located in the intestine and liv- er. Efflux membrane transporters limit the absorption of orally administered drug in the intestine and facilitate the pre-systemic elimination via bile, leading to poor bioavailability of drugs. ${ }^{38}$ A study aiming to characterize the regional absorptive and secretory kinetics of etoposide in rabbit intestinal tissues revealed that the apical to basolateral (i.e. absorptive) transport of etoposide was not apparently mediated by specialized transporters, whereas basolateral to apical (i.e. secretory) transport by intestinal tissues was concentration dependent and saturable, mediated by transporters. ${ }^{39}$

Etoposide was shown to be a substrate of several ABC transporters, notably ABCB1 (MDR1, P-glycoprotein, P-gp) and ABCC1 (MRP1), ABCC2 (MRP2), ABCC3 (MRP3) and ABCG2 (BCRP). ${ }^{40-45}$ The location of these transporters in enterocytes and hepatocytes is marked in Figure 1. Allen et al. ${ }^{40}$ showed that ABCB1 can have a substantial effect on the oral availability of etoposide, while ABCG2 can have a little effect on oral etoposide pharmacokinetics. In vitro data showed that ABCC 2 and ABCC 3 can moderately transport etoposide. ${ }^{42,43}$ Etoposide was shown to be a good ABCC1 substrate. ${ }^{44}$ Lagas et al. ${ }^{46}$ studied the impact of ABCB1, ABCC2 and ABCC3 on the pharmacokinetics of etoposide in wild-type, $\mathrm{ABCC}_{2}^{--}$, ABCB1a/1b ${ }^{-/}$, and ABCB1a/1b;ABCC2 ${ }^{-/}$ mice. Results demonstrated that $\mathrm{ABCB} 1$, which is located in apical membrane of enterocytes, restricted the oral (re)uptake of unchanged etoposide, and mediated its excretion across the gut wall, while hepatobiliary excretion of both etoposide and etoposide glucuronide were almost entirely dependent on ABCC2, and not on ABCB1. Additionally, ABCC3 was responsible for the efflux of etoposide glucuronide from the liver to the systemic blood circulation, especially when ABCC2 was absent. Authors concluded that pharmacokinetics of etoposide and etoposide glucuronide is significantly affected by ABCB1, ABCC2, and ABCC3 and that high inter-individual variability of etoposide may be explained by variation in transporter expression or activity. ${ }^{46}$

Drug metabolism principally occurs in the liver, but also other tissues, like intestinal mucosa, must be considered..$^{12}$ Etoposide is O-demethylated primarily by cytochrome P450 (CYP) 3A4 and to a lesser extent by CYP3A5. ${ }^{47,48}$ Furthermore, CYP1A2 and 2E1 are involved as the minor enzymatic components in this metabolic pathway. ${ }^{49} \mathrm{O}$-demethylated metabolite of etoposide is catehol. ${ }^{47}$ Catehol can undergo oxidation to form an ortho-quinone (and vice versa) via formation of a semi-quinone free radical. Studies suggest that radical species, in addition to the catehol and ortho-quinone, might also be involved in 


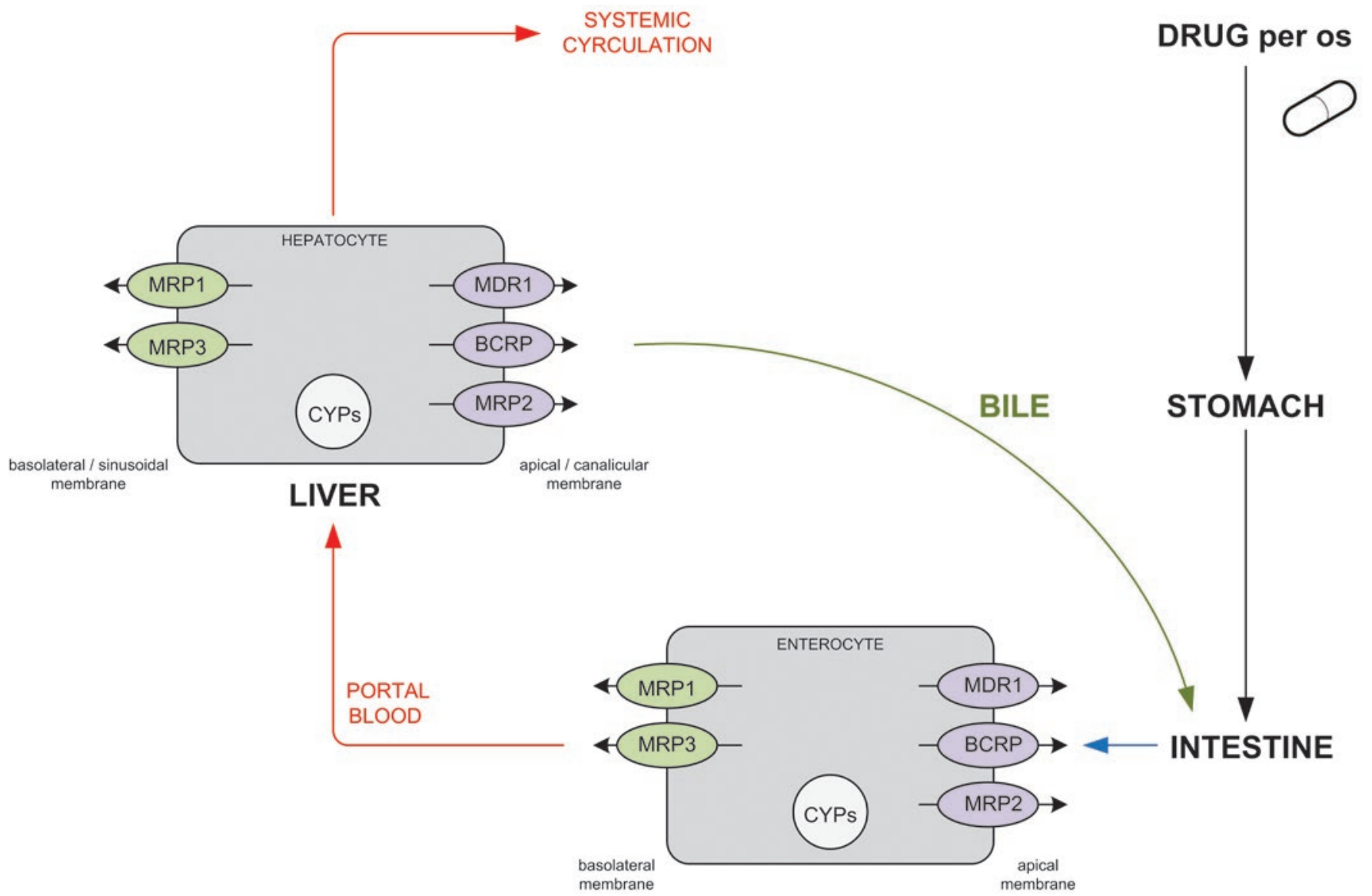

FIGURE 1. Schematic representation of the efflux transporters and metabolic enzymes (marked) possibly influencing etoposide bioavailability (modified by Ref. 58).

$M D R 1=$ multi-drug resistance protein ( $A B C B 1$, -glycoprotein); $M R P 1-3=$ multidrug resistance-associated proteins $(A B C C 1-3)$; $B C R P=$ breast-cancer resistance protein $(A B C G 2)$; CYPs = cytochrome P450

the cytotoxicity of etoposide..$^{50-52}$ Ortho-quinone is attenuated by glutathione conjugation. ${ }^{53}$ The second way of etoposide metabolism is glucuronidation, mainly catalyzed by UGT1A1. Although etoposide glucuronidation is also catalyzed by UGT1A8 and 1A3, their activities are much lower than that of UGT1A1. The predominant form of etoposide glucuronide in liver and intestine is phenolic glucuronide, whereas two alcoholic glucuronides are the minor metabolites. ${ }^{54,55}$ CYP isoform was reported to be directly involved in the oxidative metabolism of etoposide, therefore variation of the intestinal activity of this CYP isoform may directly affect the bioavailability of etoposide. ${ }^{12}$

As shown in Figure 1, once etoposide as a drug crosses the apical membrane of the enterocyte, a part is effluxed back to the intestinal lumen by ABC transporters ABCB1 (MDR1), ABCC2 (MRP2) and ABCG2 (BCRP) and part is possibly subjected to intestinal first-pass metabolism by metabolizing enzymes. The fraction of drug absorbed into the mesenteric blood circulation enters into the liver via the portal vein and may be transported from hepatocytes into the bile (metabolized or non-metabolized) or to the systemic circulation. ${ }^{56,57}$

Many enzymes and secretory transporters are subject to genetic polymorphisms with functional consequences. A complete description of these polymorphisms can be found in the article of Robert et al..$^{59}$ as well as on the dedicated websites (www.pharmgkb.org, www.imm.ki.se/CYPalleles, www.hapmap.org, www.ncbi.nlm.nih.gov/projects/ $\mathrm{SNP} /$ ). Genetic polymorphisms might be a one of the factors causing the interindividual differences in etoposide bioavailability. However, no study evaluated the association of these polymorphisms with etoposide bioavailability. Only one study explored the effect of polymorphisms in the $A B C B 1$ on etoposide pharmacokinetics. In this study $A B C B 1$ 3435TT genotype was associated with low- 
er volume of distribution and contributed significantly to the inter-individual variability observed in etoposide pharmacokinetics. ${ }^{60}$ However, effects of $A B C B 1$ polymorphisms, particularly $3435 \mathrm{C}>\mathrm{T}$, on digoxin plasma levels after oral administration were extensively studied. ${ }^{61,62}$

Summarized, genetic variability and functional polymorphisms in $\mathrm{ABC}$ transporters are relevant pharmacological factors that have to be considered together with drug-metabolizing enzymes, whose activity show a large degree of interindividual variability. ${ }^{37}$

\section{Physiological factors}

The metabolism of etoposide is partly hepatic, therefore hepatic insufficiency causes an increase in bioavailability of etoposide due to decreased first-pass effect. ${ }^{12,63}$ However, Hande et al..$^{29,30}$ stated that variation in hepatic metabolism probably does not explain differences between oral and intravenous drug administration because etoposide's hepatic clearance rate is not high. Aita et al. ${ }^{64}$ studied the pharmacokinetics of oral etoposide in patients with hepatocellular carcinoma and underlying cirrhosis. They found slightly high etoposide bioavailability and clearance resulting in a normal AUC. ${ }^{64}$ Bioavailability of etoposide was not affected neither in patients with gastric carcinoma nor in patients with gastrectomy. ${ }^{65}$

Ando et al. ${ }^{66}$ showed that gender does not affect the pharmacokinetics or pharmacodynamics of oral etoposide, while patient's age affect pharmacodynamics. Although there was no difference in pharmacokinetics between elderly (ages 75 years or older) and younger patients, equivalent exposure to etoposide resulted in greater pharmacodynamic sensitivity in elderly patients. ${ }^{66,67}$ Contrary to the results of Ando et al. ${ }^{66}$, Miyazaki et al. ${ }^{68}$ showed that, although there were no significant differences in mean AUC values, plasma clearance and urinary excretion of oral etoposide, there were significant differences in elimination half life and bioavailability in the elderly group, compared with the younger adult group; both were significantly increased in the elderly patients. In comparison with intravenous administration, there was no statistically significant difference in these parameters between the elderly and younger adult group. ${ }^{68}$

\section{Environmental factors}

Cancer patients commonly receive multiple medications, including chemotherapy and supportive care drugs, the majority of them are elderly, and so require medications for co-morbid conditions, and have age-related decline in hepatic and renal function that reduce their ability to metabolize and eliminate drugs. ${ }^{69}$ The possibility of drugdrug and drug-food interactions is therefore high. Interactions that affect bioavailability are usually pharmacokinetic interactions involving metabolising enzymes and drug transporters.

Many clinical and preclinical studies are documented wherein CYP450 and/or ABCB1 and/or UGT1A1 were prominently implicated to play an important role in etoposide bioavailability. Several CYP3A4 and ABCB1 inhibitors were described to enhance etoposide bioavailability, such as platinum compounds, cyclosporine A, hydroxyzine, quinidine, 20(S)-ginsenoside Rh2, GF120918, kaempferol, morin, quercetin, verapamil, PSC833 (valspodar), ketoconazole, piperine analogue and curcumin.

A study exploring the potential interaction between the two platinum drugs, cisplatin and carboplatin, and the oxidative metabolism of etoposide demonstrated that the interaction between etoposide and platinum drugs is small and the clinical impact is unlikely to be significant. The exact mechanism of interaction is unknown but may involve inhibition of etoposide metabolism. ${ }^{70}$

Cyclosporine $\mathrm{A}$, hydroxyzine and quinidine were shown to increase systemic etoposide exposure through inhibition of the multidrug transporter $\mathrm{ABCB} 1 .^{71-73}$ Increased $\mathrm{AUC}$ and additionally peak concentration $\left(\mathrm{c}_{\max }\right)$ was observed by co-administration of an ABCB1 inhibitor 20(S)-ginsenoside $\mathrm{Rh} 2$, a trace constituent of ginseng. ${ }^{74}$ Increased oral uptake of etoposide due to ABCB1 inhibition was shown also by GF120918.40

The oral bioavailability of etoposide increased significantly when the drug was combined with kaempferol, morin or quercetin, three ingredients of dietary supplements. Additionally, kaempferol also increased $c_{\max }$ of oral etoposide. A possible explanation to enhanced bioavailability of oral etoposide by these three aforementioned drugs could be due to an inhibition of CYP450-catalyzed metabolism and ABCB1-mediated efflux in the intestine and/or liver. ${ }^{75-77}$ Similar results were obtained with verapamil and PSC833 (valspodar), a CYP3A and ABCB1 inhibitor. ${ }^{40,78,79}$

Ketoconazole was also shown to increase systemic exposure of oral etoposide. Ketoconazole is a commonly used antifugal drug known for its inhibitory effect on CYP3A4, UGT1A1, and ABCB1. However, Peng Yong et al. ${ }^{80}$ reported that increased 
TABLE 1. Quantitative effects of etoposide interactions with various drugs that can potentially affect etoposide bioavailability

\begin{tabular}{|c|c|c|}
\hline Drug & Quantitative effect (method) & Reference \\
\hline Cisplatin or carboplatin & $\begin{array}{l}\text { Increased AUC of etoposide ( } 8 \% \text { with carboplatin, } 28 \% \text { with cisplatin) (patients, } \\
\text { in vitro methods) }\end{array}$ & Thomas et al. ${ }^{70}$ \\
\hline Cyclosporine A & Mean increase of AUC of etoposide $89 \%$ (patients) & Bisogno et al. ${ }^{71}$ \\
\hline Hydroxyzine & $\begin{array}{l}\text { Transport of etoposide increased from the luminal site to the serosal site in the } \\
\text { jejunum by } 2 \text {-fold (reduced efflux) (everted rat gut sacks) }\end{array}$ & Kan et al. ${ }^{72}$ \\
\hline Quinidine & $\begin{array}{l}\text { Increased serum concentration of oral etoposide more than 2-fold (everted gut } \\
\text { sacks prepared from rat jejunum and ileum) }\end{array}$ & Leu et $a .^{73}$ \\
\hline 20(S)-Ginsenoside Rh2 & $\begin{array}{l}\text { AUC of intragastric administration of etoposide in rats increased by } 4.52 \text {-fold; } \\
C_{\max } \text { increased by } 2.54 \text {-fold (rats) }\end{array}$ & Zhang et al. ${ }^{74}$ \\
\hline GF120918 & $\begin{array}{l}\text { Increased plasma levels of etoposide after oral administration 4-5-fold (wild-type } \\
\text { mice) }\end{array}$ & Allen et al..$^{40}$ \\
\hline Kaempferol & $\begin{array}{l}\text { The absolute bioavailability of oral etoposide increased by } 11.0-12.3 \% \text {; the } \\
\text { relative bioavailability of oral etoposide increased } 1.15-1.64 \text {-fold; significantly } \\
\text { increased } c_{\max } \text { (rats) }\end{array}$ & Li et al. ${ }^{75}$ \\
\hline Morin & Increased absolute bioavailability of oral etoposide by $35,9 \%$ (rats) & Li et al. ${ }^{76}$ \\
\hline Quercetin & $\begin{array}{l}\text { Increased absolute bioavailability of oral etoposide to } 12.7 \text { (quercetin } 5 \mathrm{mg} / \mathrm{kg} \text { ) } \\
\text { or } 13.6 \% \text { (quercetin } 15 \mathrm{mg} / \mathrm{kg} \text { ) (rats) }\end{array}$ & Li et al. ${ }^{77}$ \\
\hline Verapamil & Increased absolute bioavailability of oral etoposide by 1.38 to 1.47 -fold (rats) & Piao et al. ${ }^{78}$ \\
\hline PSC833 (valspodar) & $\begin{array}{l}\text { Increased plasma concentration of orally administered etoposide at least } \\
\text { 10-fold (rats) }\end{array}$ & Keller et al. ${ }^{79}$ \\
\hline Ketoconazole & Increased AUC of oral etoposide by a median of $20 \%$ (patients) & Peng Yong et al. ${ }^{80}$ \\
\hline $\begin{array}{l}\text { Food (standard breakfast: milk, } \\
\text { cornflakes, sugar, egg, sausage, bread, } \\
\text { margarine, orange marmalade and } \\
\text { coffee or tea, sweetened to taste) }\end{array}$ & $\begin{array}{l}\text { Decreased AUC of oral etoposide from } 40.8 \pm 10.7 \mu \mathrm{gml}^{-1} \mathrm{~h} 1.7 \mathrm{~m}^{-2} \text { to } 35.8 \pm 9.8 \mu \mathrm{gml}^{-} \\
\text {'hl. } 7 \mathrm{~m}^{-2} \text { (patients) }\end{array}$ & Harvey et al. ${ }^{81}$ \\
\hline Grapefruit juice & $\begin{array}{l}\text { Decreased AUC of oral etoposide of } 26.2 \% \text {; median absolute bioavailability of } \\
50 \mathrm{mg} \text { oral etoposide with and without pretreatment with grapefruit juice was } \\
52.4 \% \text { and } 73.2 \% \text {, respectively (patients) }\end{array}$ & Reif et al. ${ }^{82}$ \\
\hline Piperine analogue & $\begin{array}{l}\text { Increased absolute bioavailability of oral etoposide } 2.32 \text {-fold (in vitro and } \\
\text { animal-derived models) }\end{array}$ & Najar et al. ${ }^{83}$ \\
\hline Curcumin & $\begin{array}{l}\text { Increased AUC of oral etoposide by } 35.1 \% \text { (curcumin } 2 \mathrm{mg} / \mathrm{kg} \text { ) and } 50.8 \% \\
\text { (curcumin } 8 \mathrm{mg} / \mathrm{kg} \text { ); increased F of oral etoposide by } 36.0 \% \text { (curcumin } 2 \mathrm{mg} / \mathrm{kg} \text { ) } \\
\text { and } 52.0 \% \text { (curcumin } 8 \mathrm{mg} / \mathrm{kg} \text { ) (rats) }\end{array}$ & Lee et al. ${ }^{84}$ \\
\hline
\end{tabular}

systemic exposure to etoposide by ketoconazole modulation is most likely mediated through the inhibition of etoposide metabolism in the liver rather than the inhibition of the transporters in the intestine. ${ }^{80}$

The results of a study conducted by Harvey et al. ${ }^{81}$ showed that food does not significantly interfere with etoposide bioavailability, at least at doses of $100 \mathrm{mg}$. Grapefruit juice increases the bioavailability of some orally-administered drugs that are metabolized by CYP3A4. However, Reif et al. ${ }^{82}$ reported that coadministration of grapefruit juice causes an unexpected decrease in systemic exposure of oral etoposide. A possible explanation for the observed effect may be an alteration of the intestinal ABCB1-mediated transport. ${ }^{82}$ It was also shown that piperine analogue, a natural alkaloid of peppers significantly enhanced the plasma levels of etoposide. A mechanistic evaluation of this effect presented by Najar et al. ${ }^{83}$ has shown that piperine analogue modifies ABCB1 and CYP3A4-mediated drug disposition mechanisms to enhance the intestinal absorption of etoposide, while preventing its efflux and metabolic inactivation during its transit from intestine to the systemic circulation. A similar effect was observed with curcumin which significantly increased the bioavailability of oral etoposide, while the pharmacokinetics of etoposide after intravenous application was not affected. Therefore, the enhanced oral bioavailability of etoposide in the presence of curcum might be due to inhibition of ABCB1 in the small intestine and possibly due to reduced first-pass metabolism via CYP3A also in the small intestine. ${ }^{84}$

Known interactions of oral etoposide with various drugs including their quantitative effects are summarized in Table 1. To our knowledge, interactions with other drugs are not well documented; however, this does not necessarily mean no interactions exist.

Some other drugs, like ifosfamide ${ }^{34}$, phenytoin and phenobarbitone ${ }^{85}$, also modify systemic expo- 
sure (reduced AUC) of etoposide when administered concomitantly. However, in all these cases etoposide was administered intravenously.

On the other hand, low and variable etoposide bioavailability may be related also to its poor solubility in water and chemical instability in physiological fluids. Etoposide's aqueous solubility is considered as extremely low. The mean solubility of etoposide at $37^{\circ} \mathrm{C}$ over the $\mathrm{pH}$ range 1.30 to 10 is 116.44 to $167.25 \mu \mathrm{g} / \mathrm{ml}$, respectively. ${ }^{86}$ Assuming that stomach and intestine contain approximately $250 \mathrm{ml}$ of fluid, the initial amount of solute in upper gastrointestinal tract is approximately 30 to $40 \mathrm{mg}$. Therefore, solubility may play an important role in higher doses. ${ }^{39}$ Extensive degradation of etoposide is observed at $\mathrm{pH} 1.30$ and 10. The intrinsic dissolution rate of etoposide increase with temperature, however, its magnitude is far less than $1.0 \mathrm{mg} / \mathrm{min} /$ $\mathrm{cm}^{2}$ at $37^{\circ} \mathrm{C}$, i.e. the absorption is limited by the dissolution rate. Additional proof for etoposide absorption to be dissolution rate limited rather than permeation rate limited is its partition coefficient between n-octanol and water which is 9.94 at $25^{\circ} \mathrm{C}$, reflecting etoposide's high lipophilicity and consequently good permeability. The low aqueous solubility and slow intrinsic dissolution rate may account for the low and variable bioavailability of the drug. However, the problem of poor drug dissolution rate was resolved by the development of hydrophilic preparation: a soft gelatine capsule containing etoposide in the form of solution. ${ }^{87}$ Additional factors that could contribute to the low and erratic bioavailability of etoposide is its chemical instability in physiological (gastric and intestinal) solutions. It is known that $\mathrm{pH}$ of the gastrointestinal tract ranges from 1 to 8 . Considering etoposide's $\mathrm{pH}$ stability range, its maximal stability is at $\mathrm{pH}$ of $5-6.15$, while it rapidly degrades at $\mathrm{pH}<2.03$ and $\mathrm{pH}>8 .{ }^{30,86}$ In vitro studies showed that the decrease in stability in intestinal fluid at $\mathrm{pH} 7.5$ is concentration-dependent while there is no concentration effect on stability in gastric fluid at $\mathrm{pH} 3.0 .88$

\section{Safety and efficacy of oral versus intravenous etoposide in SCLC}

Safety and efficacy were shown to correlate with AUC of etoposide. Oral administration may increase the variability in AUC and may lead to a greater variability in safety and efficacy of oral etoposide..$^{30}$

The first randomized phase II study compared 3-day oral vs. intravenous etoposide schedule in combination with cisplatin in SCLC patients, and assuming $50 \%$ bioavailability. Results of this study showed that overall response rates (complete and partial response), time to progression and survival were comparable for both treatment arms. Overall toxicity for both treatment arms was similar and included neutropenia, thrombocytopenia, anemia, alopecia, nausea, diarrhea, vomiting and weight loss. Septic episodes in neutropenic patients as well as moderate to severe anemia and more than $10 \%$ weight loss occurred more frequently with the intravenous when compared with the oral treatment. Based on this data it was concluded that the oral treatment regimen could be a suitable substitute for those patients to whom parenteral therapy cannot be given. ${ }^{24}$

Comparable results in terms of response were obtained in another SCLC study which compared safety and efficacy of intravenous and oral etoposide alone, in a 5-day schedule and not assuming $50 \%$ bioavailability. Intravenous dose was $80 \mathrm{mg} /$ $\mathrm{m}^{2} /$ day while oral dose was $130 \mathrm{mg} / \mathrm{m}^{2} /$ day. Each study gave a similar response rate. The major doselimiting factor, leukopenia, was observed more frequently in the intravenous administration. Other side effects were anemia, thrombocytopenia, anorexia, nausea, and alopecia ${ }^{89,90}$

Yet, two other randomized studies compared oral and intravenous etoposide administration in combination with cisplatin for the treatment of SCLC patients. In both studies etoposide was administered intravenously for 3 days and oral etoposide was administered for 21 days. Selfevidently, the daily dose of intravenously administered etoposide was higher than the dose of orally administered one, while the cumulative dose of etoposide per cycle was higher for orally administered etoposide. Results of both studies showed that the two schedules of etoposide in combination with cisplatin did not result in significant differences in treatment outcome with respect to tumor response and survival. However, a significantly greater rate of hematologic toxicity was noted in intravenous etoposide treatment schedule in the first study ${ }^{91}$ and in oral etoposide treatment schedule in the second one..$^{92}$

As expected, two randomized trials in patients with SCLC demonstrated that oral etoposide alone was inferior to intravenous combination treatment. Of note, although being less effective, oral etoposide alone was associated in the first trial with increased toxicity. However, in both studies intravenous etoposide was used in combined regimens with cisplatin or cyclophosphamide, doxorubicin, 
and vincristine, while oral etoposide was administered as monochemotherapy. Treatment schedules of oral and intravenous etoposide were also very different. $.33,94$

Aforementioned clinical trials are described in detail in Table 2.

\section{Improvement of bioavailability of oral etoposide}

\section{Concomitant medications}

Several strategies were explored to improve low and variable bioavailability of oral etoposide. A potential strategy for diminishing variability of oral etoposide is to minimize the sources of variability. Cancer patients are at especially high risk for drug interactions because they commonly receive multiple drugs. In addition, it is estimated that $50 \%$ of cancer patients use alternative and herbal medicines, often without their doctor's knowledge. To diminish these risks, it is important to take an accurate medication history which should be updated at each visit. However, all predictable drug interactions are not always avoidable. ${ }^{69}$

Some drugs were reported to be intentionally used to modulate oral availability of etoposide when administered concomitantly. The increase in bioavailability is a consequence of inhibition of metabolic enzymes and/or efflux transporters. One of these drugs is ketoconazole. ${ }^{80}$ Combined use of etoposide with inhibitors of metabolizing enzymes and/or efflux transporters increases etoposide's bioavailability. Allen et al..$^{40}$ stated that raising the bioavailability closer to $100 \%$ might eliminate some variability and allow better control of etoposide exposure. On the contrary, Peng Yong et al. ${ }^{80}$ showed that ketoconazole does not reduce the variability.

However, modulation of intestinal absorption of drugs that are substrates of metabolic enzymes and transporters is further complicated by the recognition that polymorphic enzymes and transporters can modulate drug uptake. ${ }^{95}$

\section{Impact on drug and/or drug delivery system}

To maximise bioavailability of oral etoposide, efforts should focus on ensuring rapid drug dissolution in the upper gastrointestinal tract, or delaying drug release to target the upper colon. These suggestions are based on results of directional study of etoposide from rabbit small intestine and colon which showed that secretory permeability was greatest in the ileum, whereas values in the upper small intestine and colon were approximately equal, and represented only $50 \%$ of the value in the ileum. ${ }^{39}$

Moreover, Zhang et al. ${ }^{96}$ have successfully incorporated etoposide into various modified nanostructured lipid carriers. Pharmacokinetic studies revealed improved relative bioavailability (more than 3.5-fold) of etoposide nanostructured lipid carriers to etoposide suspension in rats after oral administration. They elucidated that the enhanced bioavailability by the modified nanostructured lipid carrier formulation might be attributed to uptake of nanoparticles through the GI tract, increased permeability by surfactants, and decreased degradation and clearance. ${ }^{96}$ Furthermore, $\mathrm{Wu}$ et al. ${ }^{97}$ developed a phospholipid complex selfemulsifying drug delivery system. Compared with etoposide suspension, the relative bioavailability of this formulation after oral administration in rats was enhanced by 60.21 -fold. ${ }^{97}$ Zhang et al. ${ }^{98}$ used natural solubilizer rubusoside to form etoposiderubusoside nanoparticles. This method showed a better solubilization effect and capability of improving physical and chemical stability profiles than a softgel capsule containing etoposide in a vehicle consisting of citric acid, glycerin, purified water, and polyethylene glycol 400. This may improve bioavailability and clinical efficacy as well as improve safety, benefiting from the GRAS (generally regarded as safe) status of rubusoside. ${ }^{98}$ On another point, Mo et al. ${ }^{99}$ suggested N-octyl-O-sulfate chitosan to be used as a formulation excipient for etoposide, since it has a potential by inhibiting $\mathrm{ABCB} 1$ to improve the absorption of etoposide.

Etoposide phosphate, a more water-soluble prodrug of etoposide has also been suggested for oral administration in an attempt to increase bioavailability and reduce inter-individual variability. Chabot et al. ${ }^{100}$ reported a $19 \%$ higher extent of absorption for etoposide phosphate compared with literature data for oral etoposide while Sessa et al. ${ }^{101}$ reported comparable or only slightly better bioavailability of etoposide phosphate compared with oral etoposide. de Jong et al. ${ }^{102}$ found a small significant increase in bioavailability but inter-individual variability of bioavailability appeared to be unaltered.

\section{Influence on the rate of gastric emptying}

Joel et al. ${ }^{27}$ investigated the use of agents that may influence etoposide stability in gastrointestinal tract and, thereby, bioavailability. Results showed that drugs that influence the rate of gastric empty- 
TABLE 2. Clinical trials evaluating safety and efficacy of oral vs. intravenous (i.v.) etoposide regimen in SCLC

\begin{tabular}{|c|c|c|c|c|c|c|}
\hline \multirow[b]{2}{*}{ Trial(ref.) } & \multirow[b]{2}{*}{$\begin{array}{l}\text { Sample } \\
\text { size }\end{array}$} & \multirow[b]{2}{*}{ Treatment regimen } & \multicolumn{4}{|c|}{ Results (oral etoposide regimen vs. i.v. etoposide regimen) } \\
\hline & & & $\begin{array}{l}\text { ORR } \\
(\%)\end{array}$ & $\begin{array}{l}\text { mPFS } \\
\text { (months) }\end{array}$ & $\begin{array}{l}\text { mOS } \\
\text { (months) }\end{array}$ & toxicity \\
\hline $\begin{array}{l}\text { Randomized } \\
\text { phase } \|^{24}\end{array}$ & $\begin{array}{l}83 \\
\text { patients }\end{array}$ & $\begin{array}{l}\text { i.v. etoposide regimen (41 patients): } \\
\text { cisplatin } 100 \mathrm{mg} / \mathrm{m}^{2} \text { i.v. day } 1 \text {, } \\
\text { etoposide } 120 \mathrm{mg} / \mathrm{m}^{2} \text { i.v. day } 1-3 \\
\text { oral etoposide regimen (42 patients): } \\
\text { cisplatin } 100 \mathrm{mg} / \mathrm{m}^{2} \text { i.v. day } 1 \text {, etoposide } 120 \mathrm{mg} / \mathrm{m}^{2} \\
\text { i.v. day } 1 \text { and } 240 \mathrm{mg} / \mathrm{m}^{2} \text { orally day } 2 \text { and } 3 \\
\text { Every } 4 \text { weeks, maximum of } 6 \text { cycles. }\end{array}$ & 50 vs. 59 & 5.9 vs. 6.6 & $\begin{array}{l}8.6 \text { for } \\
\text { either } \\
\text { treatment } \\
\text { arm }\end{array}$ & $\begin{array}{l}\text { hematologic toxicity } \\
\text { comparable in both } \\
\text { treatment arms, } \\
\text { infectious episodes, } \\
\text { moderate to severe } \\
\text { anemia and weight loss } \\
\text { more predominant with } \\
\text { the i.v regimen }\end{array}$ \\
\hline $\begin{array}{l}\text { Randomized } \\
\text { phase } \| 89,90\end{array}$ & $\begin{array}{l}47 \\
\text { patients }\end{array}$ & $\begin{array}{l}\text { i.v. etoposide regimen ( } 22 \text { patients): } \\
\text { etoposide } 80 \mathrm{mg} / \mathrm{m}^{2} \text { i.v. } 5 \text { consecutive days } \\
\text { oral etoposide regimen ( } 25 \text { patients): } \\
\text { etoposide } 130 \mathrm{mg} / \mathrm{m}^{2} \text { orally } 5 \text { consecutive days }\end{array}$ & $\begin{array}{l}\text { similar } \\
\text { for either } \\
\text { treatment } \\
\text { arm } \\
\text { (PR: } 28 \text { vs. } \\
36.4 \text { ) }\end{array}$ & / & / & $\begin{array}{l}\text { leukopenia observed in } \\
32 \% \text { patients of the oral } \\
\text { administration and in } \\
59 \% \text { patients of the i.v. } \\
\text { administration }\end{array}$ \\
\hline $\begin{array}{l}\text { Randomized } \\
\text { trial }^{91}\end{array}$ & $\begin{array}{l}21 \\
\text { patients }\end{array}$ & $\begin{array}{l}\text { i.v. etoposide regimen ( } 14 \text { patients): } \\
\text { cisplatin } 80 \mathrm{mg} / \mathrm{m}^{2} \text { i.v. day } 1 \text {, etoposide } 100 \mathrm{mg} / \mathrm{m}^{2} \\
\text { i.v. day } 2,3 \text { and } 4 \\
\text { oral etoposide regimen ( } 7 \text { patients): } \\
\text { cisplatin } 80 \mathrm{mg} / \mathrm{m}^{2} \text { i.v. day } 1 \text {, etoposide } 50 \mathrm{mg} \\
\text { orally day } 3-23\end{array}$ & 86 vs. 64 & / & $\begin{array}{l}\text { no } \\
\text { significant } \\
\text { difference }\end{array}$ & $\begin{array}{l}\text { hematologic toxicity } \\
\text { less severe for oral } \\
\text { regimen than for i.v. } \\
\text { regimen }\end{array}$ \\
\hline $\begin{array}{l}\text { Randomized } \\
\text { phase } 11^{192}\end{array}$ & 306 & $\begin{array}{l}\text { Both regimens were repeated every } 4 \text { weeks. } \\
\text { i.v. etoposide regimen: } \\
\text { cisplatin } 25 \mathrm{mg} / \mathrm{m}^{2} \text { i.v. } 3 \text { days, } \\
\text { etoposide } 130 \mathrm{mg} / \mathrm{m}^{2} \text { i.v. } 3 \text { days } \\
\text { Regimen was repeated every } 21 \text { days for } 8 \text { cycles. } \\
\text { oral etoposide regimen: } \\
\text { cisplatin } 33 \mathrm{mg} / \mathrm{m}^{2} \text { i.v. } 3 \text { days, } \\
\text { etoposide } 50 \mathrm{mg} / \mathrm{m}^{2} \text { orally } 21 \text { days } \\
\text { Regimen was repeated every } 28 \text { days for } 6 \text { cycles. }\end{array}$ & $\begin{array}{l}14 \text { vs. } 15 \\
\text { (PR: } 47 \text { vs. } \\
\text { 42) }\end{array}$ & $\begin{array}{l}7 \text { months } \\
\text { for either } \\
\text { treatment } \\
\text { arm }\end{array}$ & 9.9 vs. 9.5 & $\begin{array}{l}\text { lethal toxicity due } \\
\text { to neutropenia and } \\
\text { infection: in } 10 \% \\
\text { of patients on oral } \\
\text { etoposide regimen and } \\
\text { in } 4 \% \text { on i.v. etoposide } \\
\text { regimen (difference not } \\
\text { statistically significant) }\end{array}$ \\
\hline $\begin{array}{l}\text { Randomized } \\
\text { trial }{ }^{93}\end{array}$ & $\begin{array}{l}339 \\
\text { patients }\end{array}$ & $\begin{array}{l}\text { i.v. etoposide regimen ( } 168 \text { patients): } \\
\text { standard intravenous regimen of etoposide and } \\
\text { vincristine, or cyclophosphamide, doxorubicin, and } \\
\text { vincristine, } 4 \text { cycles } \\
\text { oral etoposide regimen ( } 171 \text { patients): } \\
\text { etoposide } 50 \mathrm{mg} \text { orally twice daily for } 10 \text { days, } \\
4 \text { cycles }\end{array}$ & 45 vs. 51 & / & 4.3 vs. 6.1 & $\begin{array}{l}\text { grade } 2 \text { or worse } \\
\text { haematological toxicity: } \\
\text { in } 29 \% \text { of patients on } \\
\text { oral etoposide regimen } \\
\text { and in } 21 \% \text { on i.v. } \\
\text { etoposide regimen }\end{array}$ \\
\hline & & $\begin{array}{l}\text { oral etoposide regimen ( } 75 \text { patients): } \\
\text { etoposide } 100 \mathrm{mg} \text { orally twice daily for } 5 \text { days }\end{array}$ & & & & \\
\hline & & $\begin{array}{l}\text { Both regimens were repeated every } 21 \text { days for } \\
6 \text { cycles. }\end{array}$ & & & & \\
\hline
\end{tabular}

ORR = overall response rate; $\mathrm{mPFS}=$ median progression free survival; $\mathrm{mOS}=$ median overall survival; $\mathrm{PR}=$ partial respons

ing (metoclopramide, propantheline), improve the stability of etoposide in artificial intestinal fluid (ethanol, bile salts), and that drugs that decrease stomach acidity (cimetidine) had no significant effect on improving the etoposide AUC. ${ }^{27}$

\section{Individualization of etoposide dosage}

Currently, the dose of etoposide is adjusted according to the body-surface area of the individual patient, but this does not yield the desired minimi- zation in individual variation in the pharmacokinetics in adults. ${ }^{103}$

Etoposide is a suitable drug for pharmacokinetically guided dosing, because of its marked inter-individual pharmacokinetic variability, but relatively little intra-patient variation. ${ }^{104}$ Various studies have been performed with dose adjustments based on pharmacokinetic sampling. These studies have involved the administration of etoposide orally or intravenously to treat patients with different kinds of cancer. 
Optimisation of oral etoposide dosage was investigated by El-Yazigi et al. ${ }^{105}$ in elderly patients with non-Hodgkin's lymphoma using individual fraction of dose absorbed and the therapeutic drug monitoring (TDM) approach. The extent of absorption (F) was calculated from the AUC generated from first oral and intravenous doses in the same patient. Etoposide was than given orally at a daily dose equivalent to $\mathrm{D}_{\text {oral }} / \mathrm{F}$. The data obtained indicated that adjustment of the oral dose of etoposide in specific group of patients using individual bioavailability data and TDM approach yielded good safety and efficacy results while keeping the toxicity at the level that is similar to that of the intravenous administration. ${ }^{105}$

AUC is the best pharmacokinetic parameter for predicting anticancer pharmacodynamic effects. Precise estimation of AUC based on plasma concentration requires the handling of many blood samples, usually $8-12$, which is expensive, timeconsuming and inconvenient. ${ }^{12,106}$ Several limited sampling models (LSM) that are based only on a few sparse determinations of plasma concentrations and can obtain a good estimate of the AUC for oral etoposide, were developed and validated. ${ }^{107-109}$ Several such models were developed also for intravenous etoposide. ${ }^{106,110-112}$ The use of LSM in targeted dosing study was used in oral etoposide by Ando et al. ${ }^{113}$ and in intravenous etoposide by Lowis et al. ${ }^{114}$ Ando et al.${ }^{113}$ reported that during the first 4 days of chemotherapy, one 25-mg capsule was taken three times daily. On day 5 , the number of etoposide capsules was adjusted to the individualized dose, depending on the mean etoposide concentration on days 3 and 4 , to achieve target concentration range of 1.0 to $1.5 \mu \mathrm{g} / \mathrm{ml} .{ }^{113}$

Another approach to optimizing etoposide dosing is to use population pharmacokinetics, which quantify pharmacokinetic variability among individuals who are the target population, and tries to explain the sources of variability. Individual pharmacokinetic parameters are estimated using the Bayesian approach by combining the population pharmacokinetic model with a limited number of plasma drug concentration measurments. 12,115

A population pharmacokinetics of oral etoposide was studied in patients with various tumor types by Nguyen et al. ${ }^{116}$ and Toffoli et al. ${ }^{117}$ They indicated that the renal function is the most important variable to be taken into account in etoposide dosing. ${ }^{116,117}$
Ciccolini et al. ${ }^{118}$ presented a Bayesian method for performing dose adjustment of etoposide when administered intravenously. A Bayesian method was proven to efficiently adjust the experimental values to the target values, thus suggesting that this approach could be routinely used for therapeutic drug monitoring of etoposide. ${ }^{118}$

Functional polymorphisms in metabolizing enzymes and $A B C$ transporters are another relevant factors that have to be considered in personalized medicine. The determination of functional polymorphisms in individual patient enables the use of genotype-based dose administration, to ensure minimal adverse drug reactions and maximal therapeutic efficacy. ${ }^{37,119}$

On the other hand, pharmacodynamic model was developed and tested for TDM of 21-day oral etoposide in non-small cell lung cancer patients. The model was developed to predict the value of the neutrophil nadir as a function of the etoposide concentration. Depending of the target nadir (grade 3 neutropenia), the dose was adjusted. However, the pharmacodynamic model yields statistically significant results only when considering the population of patients. Conversely, when applied to individual patients for TDM, the model lacks accuracy and precision. ${ }^{120,121}$

\section{Conclusions}

Generally, oral etoposide administration compared to intraveneous administration may result in an improvement of patient's quality of life and reduced costs. Several studies confirmed comparable safety and efficacy of oral and intravenous etoposide. However, a greater use of oral etoposide is limited by its incomplete and variable bioavailability. Many researchers studied various factors that may influence etoposide bioavailability and, attempted to tailor etoposide dose to the individual patient. The strategy of limited sampling and estimation of individual pharmacokinetic parameters by the Bayesian method seems to efficiently adjust experimental values to the target value. Furthermore, dosage adjustment based on pharmacogenetic analysis may be of great importance for individualized treatment of cancer patients in future. Therefore, further studies are needed to show the accuracy and precision of Bayesian method and pharmacogenetic analysis in dosage adjustment of oral etoposide in SCLC patients. 


\section{References}

1. Chabner BA, Bertino J, Cleary J, Ortiz T, Lane A, Supko JG, et al. Chapter 61. Cytotoxic agents. In: Brunton LL, Chabner BA, Knollmann BC, editors. Goodman \& Gilman's The pharmacological basis of therapeutics. 12th edition. New York: McGraw-Hill; 2011. Available from: http://www.accessmedicine.com/content.aspx?alD=16680251. Accessed April 16, 2012.

2. Sørensen M, Pijls-Johannesma M, Felip E. Small-cell lung cancer: ESMO Clinical Practice Guidelines for diagnosis, treatment and follow-up. Ann Oncol 2010; 21(Suppl 5): v120-5.

3. Kuo YH, Lin ZZ, Yang YY, Shao YY, Shau WY, Kuo RN, et al. Survival of patients with small cell lung carcinoma in Taiwan. Oncology 2012; 82: 19-24.

4. Kagohashi K, Ohara G, Satoh H, Sekizawa K. Chemotherapy for small-cell lung cancer with paraneoplastic nephritic syndrome. Radiol Oncol 2004; 38: 153-4.

5. Dolenšek M, Bavčar Vodovnik T. [Imaging detetection in early lung cancer]. [Slovenian]. Radiol Oncol 2006; 40(Suppl 1): S53-8.

6. Panov SZ. Molecular biology of the lung cancer. Radiol Oncol 2005; 39: 197-210.

7. Terčelj M. [Early detetection of lung cancer]. [Slovenian]. Radiol Oncol 2006; 40(Suppl 1): S59-66.

8. Warde P, Payne D. Does thoracic irradiation improve survival and local control in limited-stage small-cell carcinoma of the lung? A meta-analysis. J Clin Oncol 1992; 10: 890-5.

9. Noda K, Nishiwaki Y, Kawahara M, Negoro S, Sugiura T, Yokoyama A, et al. Irinotecan plus cisplatin compared with etoposide plus cisplatin for extensive small-cell lung cancer. N Engl J Med 2002; 346: 85-91.

10. Hanna N, Bunn PA Jr, Langer C, Einhorn L, Guthrie T Jr, Beck T, et al. Randomized phase III trial comparing irinotecan/cisplatin with etoposide/ cisplatin in patients with previously untreated extensive-stage disease small-cell lung cancer. J Clin Oncol 2006; 24: 2038-43.

11. Califano R, Abidin AZ, Peck R, Faivre-Finn C, Lorigan P. Management of small cell lung cancer. Recent Developments for Optimal Care. Drugs 2012; 72: $471-90$.

12. Toffoli G, Corona G, Basso B, Boiocchi M. Pharmacokinetic optimisation of treatment with oral etoposide. Clin Pharmacokinet 2004; 43: 441-6.

13. Montecucco A, Biamonti G. Cellular response to etoposide treatment. Cancer Lett 2007; 252: 9-18.

14. Hande KR. The importance of drug scheduling in cancer chemotherapy: etoposide as an example. Oncologist 1996; 1: 234-9.

15. Greco FA, Johnson DH, Hande KR, Porter LL, Hainsworth JD, Wolff SN. High-dose etoposide (VP-16) in small-cell lung cancer. Semin Oncol 1985; 12(Suppl 2): 42-4

16. Slevin ML, Clark PI, Joel SP, Malik S, Osborne RJ, Gregory WM, et al. A randomized trial to evaluate the effect of schedule on the activity of etoposide in small-cell lung cancer. J Clin Oncol 1989; 7: 1333-40.

17. Miller AA, Herndon JE II, Hollis DR, Ellerton J, Langleben A, Richards F II, et al. Schedule dependency of 21-day oral versus 3-day intravenous etoposide in combination with intravenous cisplatin in extensive stage small-cell lung cancer: A randomized phase III study of the cancer and leukemia group B. Clin Oncol 1995; 13: 1871-9.

18. Seiter K. Toxicity of the topoisomerase II inhibitors. Expert Opin Drug Saf 2005; 4: 219-34.

19. 19 Clark PI. Current role of oral etoposide in the management of small cell lung cancer. Drugs 1999: 58(Suppl 3): 17-20.

20. Greco FA, Hainsworth JD. Prolonged administration of low-daily dose etoposide: a superior dosing schedule? Cancer Chemother Pharmacol 1994; 34: 101-4.

21. Sørensen M, Felip E. Small-cell lung cancer: ESMO Clinical Recommendations for diagnosis, treatment and follow-up. Ann Oncol 2009; 20(Suppl 4): iv71-2.

22. Liu G, Franssen E, Fitch MI, Warner E. Patient preferences for oral versus intravenous palliative chemotherapy. J Clin Oncol 1997; 15: 110-5.
23. Payne SA. A study of quality of life in cancer patients receiving palliative chemotherapy. Soc Sci Med 1992; 35: 1505-9.

24. Johnson DH, Ruckdeschel JC, Keller JH, Lyman GH, Kallas GJ, Macdonald $J$, et al. A randomized trial to compare intravenous and oral etoposide in combination with cisplatin for the treatment of small cell lung cancer. Cancer 1991; 67: 245-9.

25. Pashko $\mathrm{S}$, Johnson $\mathrm{DH}$. Potential cost savings of oral versus intravenous etoposide in the treatment of small cell lung cancer. Pharmacoeconomics 1992; 1: 293-7.

26. Fujiwara Y, Ohune T, Okusaki K, Niitani K, Sumiyoski H, Takemoto V, et al. Bioavailability of 50 - and $75-\mathrm{mg}$ oral etoposide in lung cancer patients. Cancer Chemother Pharmacol 1996; 37: 327-31.

27. Joel SP, Clark PI, Heap L, Webster L, Robbins S, Craft H, et al. Pharmacological attempts to improve the bioavailability of oral etoposide. Cancer Chemother Pharmacol 1995; 37: 125-33.

28. Harvey VJ, Slevin ML, Joel SP, Barnett MJ, Smythe MM, Ang LM, et al. The pharmacokinetics of oral etoposide (VP16-213). Proc Am Soc Clin Oncol 1984; 3: 24.

29. Hande KR, Krozely MG, Greco FA, Hainsworth JD, Johnson DH. Bioavailability of low-dose oral etoposide. J Clin Oncol 1993; 11: 374-7.

30. Hande K, Messenger M, Wagner J, Krozely M, Kaul S. Inter- and intrapatient variability in etoposide kinetics with oral and intravenous drug administration. Clin Cancer Res 1999; 5: 2742-7.

31. Würthwein $G$, Krümpelmann S, Tillmann B, Real E, Schulze-Westhoff $P$, Jürgens $\mathrm{H}$, et al. Population pharmacokinetic approach to compare ora and i.v. administration of etoposide. Anti-Cancer Drugs 1999; 10: 807-14.

32. Slevin ML, Joel SP, Whomsley R, Devenport K, Harvey VJ, Osborne RJ, et al. The effect of dose on the bioavailability of oral etoposide: confirmation of a clinically relevant observation. Cancer Chemother Pharmacol 1989; 24: 329-31.

33. Desoize B, Maréchal F, Cattan A. Correlations between clinical pharmacodynamics and pharmacokinetics of cisplatin and etoposide. Ann Biol Clin 1993; 51: 125-8.

34. You B, Tranchand B, Girard P, Falandry C, Ribba B, Chabaud S, et al. Etoposide pharmacokinetics and survival in patients with small cell lung cancer: A multicentre study. Lung Cancer 2008; 62: 261-72.

35. Roden DM. Chapter 5. Principles of Clinical Pharmacology. In: Longo DL, Fauci AS, Kasper DL, Hauser SL, Jameson JL, Loscalzo J, editors. Harrison's principles of internal medicine. 18th edition. New York: McGrawHill; 2012. Available form: http://www.accessmedicine.com/content. aspx?alD=9092427. Accessed April 16, 2012.

36. Franke RM, Gardner ER, Sparreboom A. Pharmacogenetics of drug transporters. Curr Pharm Des 2010; 16: 220-30.

37. Brinkmann U, Roots I, Eichelbaum M. Pharmacogenetics of the human drug-transporter gene MDR1: impact of polymorphisms on pharmacotherapy. Drug Discov Today 2001; 6: 835-9.

38. Dietrich CG, Geier A, Oude Elferink RPJ. ABC of oral bioavailability: transporters as gatekeepers in the gut. Gut 2003; 52: 1788-95.

39. Kunta J, Yan J, Makhey VD, Sinko PJ. Active efflux kinetics of etoposide from rabbit small intestine and colon. Biopharm Drug Dispos 2000; 21: 83-93.

40. Allen JD, van Dort SC, Buitelaar M, van Tellingen O, Schinkel AH. Mouse breast cancer resistance protein (Bcrp1/Abcg2) mediates etoposide resistance and transport, but etoposide oral availability is limited primarily by P-glycoprotein. Cancer Res 2003; 63: 1339-44.

41. Guo A, Marinaro W, Hu P, Sinko PJ. Delineating the contribution of secretory transporters in the efflux of etoposide using Madin-Darby canine kidney (MDCK) cells overexpressing P-glycoprotein (Pgp), multidrug resistanceassociated protein (MRP1), and canalicular multispecific organic anion transporter (cMOAT). Drug Metab Dispos 2002; 30: 457-63.

42. Cui Y, Konig J, Buchholz JK, Spring H, Leier I, Keppler D. Drug resistance and ATP-dependent conjugate transport mediated by the apikal multidrug resistance protein, MRP2, permanently expressed in human and canine cells. Mol Pharmacol 1999; 55: 929-37.

43. Kool M, van der Linden $M$, de Haas M, Scheffer GL, de Vree JM, Smith AJ, et al. MRP3, an organic anion transporter able to transport anti-cancer drugs. Proc Nat Acad Sci USA 1999; 96: 6914-9. 
44. Wijnholds J, Scheffer GL, van der Valk M, van der Valk P, Beijnen JH, Scheper RJ, et al. Multidrug resistance protein 1 protects the oropharyngeal mucosal layer and the testicular tubules against drug-induced damage. $J$ Exp Med 1998; 188: 797-808.

45. Stephens RH, O'Neill CA, Bennett J, Humphrey M, Henry B, Rowland M. Resolution of P-glycoprotein effects on drug permeability using intestinal tissues from mdr1a (-/-) mice. Br J Pharmacol 2002; 135: 2038-46.

46. Lagas JS, Fan L, Wagenaar E, Vlaming MLH, van Tellingen O, Beijnen JH, et al. P-glycoprotein (P-gp/Abcb1), Abcc2, and Abcc3 determine the pharmacokinetics of etoposide. Clin Cancer Res 2010; 16: 130-40.

47. Relling MV, Nemec J, Schuetz EG, Schuetz JD, Gonzalez FJ, Korzekwa KR. O-demethylation of epipodophyllotoxins is catalyzed by human cytochrome P450 3A4. Mol Pharmacol 1994; 45: 352-8.

48. Zhuo X, Zheng N, Felix CA, Blair IA. Kinetics and regulation of cytochrome P450-mediated etoposide metabolism. Drug Metab Dispos 2004; 32: 993-1000.

49. Kawashiro T, Yamashita K, Zhao X-J, Koyama E, Tani M, Chiba K, et al. A study on the metabolism of etoposide and possible interactions with antitumor or supporting agents by human liver microsomes. J Pharmacol Exp Ther 1998; 286: 1294-300.

50. Mans DRA, Retèl J, van Maanen JMS, Lafleur MVM, van Schaik MA, Pinedo $\mathrm{HM}$, et al. Role of the semi-quinone free radical of the anti-tumor agent etoposide (VP-16-213) in the inactivation of single- and double-stranded ФX174 DNA. Br J Cancer 1990; 62: 54-60.

51. van Maanen JMS, de Vries J, Pappie D, van den Akker E, Lafleur MVM, Retè $\mathrm{J}$, et al. Cytochrome P-450-mediated O-demethylation: A route in the metabolic activation of etoposide (VP-16-213). Cancer Res 1987; 47: 4658-62.

52. Haim N, Nemec J, Roman J, Sinha BK. In vitro metabolism of etoposide (VP-16-213) by liver microsomes and irreversible binding of reactive intermediates to microsomal proteins. Biochem Pharmacol 1987; 36: 527-36.

53. Mans DR, Lafleur MV, Westmijze EJ, Horn IR, Bets D, Schuurhuis GJ, et al. Reactions of glutathione with the catehol, the ortho-quinone and the semi-quinone free radical of etoposide. Consequences for DNA inactivation. Biochem Pharmacol 1992; 43: 1761-8.

54. Wen Z, Tallman MN, Ali SY, Smith PC. UDP-glucuronosyltransferase 1A1 Is the principal enzyme responsible for etoposide glucuronidation in human liver and intestinal microsomes: Structural characterization of phenolic and alcoholic glucuronides of etoposide and estimation of enzyme kinetics. Drug Metab Dispos 2007; 35: 371-80.

55. Watanabe Y, Nakajima M, Ohashi N, Kume T, Yokoi T. Glucuronidation of etoposide in human liver microsomes is specifically catalyzed by UDPglucuronosyltransferase 1A1. Drug Metab Dispos 2003; 31: 589-95.

56. Del Amo EM, Heikkinen AT, Mönkkönen J. In vitro-in vivo correlation in p-glycoprotein mediated transport in intestinal absorption. Eur J Pharm Sci 2009; 36: 200-11.

57. Matheny CJ, Lamb MW, Brouwer KR, Pollack GM. Pharmacokinetic and pharmacodynamic implications of P-glycoprotein modulation. Pharmacotherapy 2001; 21: 778-96.

58. Kerb R. Implications of genetic polymorphisms in drug transporters for pharmacotherapy. Cancer Lett 2006; 234: 4-33.

59. Robert J, Le Morvan V, Smith D, Pourquier P, Bonnet J. Predicting drug response and toxicity based on gene polymorphisms. Crit Rev Oncol Hematol 2005; 54: 171-96.

60. Strother RM, Jones D, Li L, Younger A, Einhorn LH, Williams S, et al. Effect of the C3435T genetic polymorphism in MDR1 on etoposide pharmacokinetics. J Clin Oncol 2008; 26 (May 20 suppl; abstr 2500).

61. Hoffmeyer S, Burk O, von Richter O, Arnold H, Brockmoller J, Johne A, et al. Functional polymorphisms of the human multidrug-resistance gene: multiple sequence variations and correlation of one allele with P-glycoprotein expression and activity in vivo. Proc Natl Acad Sci USA 2000; 97: 3473-8.

62. Nakamura T, Sakaeda T, Horinouchi M, Tamura T, Aoyama N, Shirakawa T, et al. Effect of the mutation (C3435T) at exon 26 on the MDR1 gene on expression level of MDR1 messenger ribonucleic acid in duodenal enterocytes of healthy Japanese subjects. Clin Pharmacol Ther 2002; 71: 297-303.

63. Gerritsen-van Schieveen P, Royer B. Level of evidence for therapeutic drug monitoring for etoposide after oral administration. Fundam Clin Pharmacol 2011; 25: 277-82.
64. Aita P, Robieux I, Sorio R, Tumolo S, Corona G, Cannizzaro R, et al. Pharmacokinetics of oral etoposide in patients with hepatocellular carcinoma. Cancer Chemother Pharmacol 1999; 43: 287-94.

65. Taal BG, Beijnen JH, Teller FG, ten Bokkel Huinink WW, Dubbelman R, Boot H. Bioavailability of oral etoposide in gastric cancer. Eur J Cancer 1994 30A: 420-1.

66. Ando $M$, Minami $H$, Ando $Y$, Sakai $S$, Shimono $Y$, Sugiura $S$, et al. Pharmacological analysis of etoposide in elderly patients with lung cancer Clin Cancer Res 1999; 5: 1690-5.

67. Fijiwara Y, Ohune T, Niitani K, Okusaki K, Sumiyoshi H, Ohashi N. Clinical pharmacological profile of etoposide in the elderly. Proc Am Soc Clin Oncol 1996; 15: 174

68. Miyazaki M, Fujiwara Y, Oguri T, Takahashi T, Ohune T, Sumiyoshi H, et al. Clinical pharmacological profile of etoposide in elderly patients with lung cancer. Asia Pac J Clin Oncol 2005; 1: 92-7.

69. Blower P, de Wit R, Goodin S, Aapro M. Drug-drug interactions in oncology: Why are they important and can they be minimized? Crit Rev Oncol Hematol 2005; 55: 117-42.

70. Thomas HD, Porter DJ, Bartelink I, Nobbs JR, Cole M, Elliott S, et al Randomized cross-over clinical trial to study potential pharmacokinetic interactions between cisplatin or carboplatin and etoposide. $\mathrm{Br} J \mathrm{Clin}$ Pharmacol 2002, 53: 83-91.

71. Bisogno G, Cowie F, Boddy A, Thomas HD, Dick G, Pinkerton CR. High-dose cyclosporin with etoposide - toxicity and pharmacokinetic interaction in children with solid tumors. Br J Cancer 1998; 77: 2304-9.

72. Kan WM, Liu YT, Hsiao CL, Shieh CY, Kuo JH, Huang JD, et al. Effect of hydroxizide on the transport of etoposide in rat small intestine. Anticancer Drugs 2011; 12: 267-73.

73. Leu BL, Huang JD. Inhibition of intestinal P-glycoprotein and effects on etoposide absorption. Cancer Chemother Pharmacol 1995; 35: 432-6.

74. Zhang J, Zhou F, Wu X, Gu Y, Ai H, Zheng Y, et al. 20(S)-Ginsenoside Rh2 noncompetitively inhibits P-glycoprotein in vitro and in vivo: A case for herb-drug interactions. Drug Metab Dispos 2010; 38: 2179-87.

75. Li C, Li X, Choi JS. Enhanced bioavailability of etoposide after oral or intravenous administration of etoposide with kaempferol in rats. Arch Pharm Res 2009; 32: 133-8.

76. Li X, Yun JK, Choi JS. Effects of morin on the pharmacokinetics of etoposide in rats. Biopharm Drug Dispos 2007; 28: 151-6.

77. Li X, Choi JS. Effects of quercetin on the pharmacokinetics of Etoposide after oral or intravenous administration of etoposide in rats. Anticancer Res 2009; 29: 1411-5.

78. Piao YJ, Li X, Choi JS. Effects of verapamil on etoposide pharmacokinetics after intravenous and oral administration in rats. Eur J Drug Metab Pharmacokinet 2008; 33: 159-64.

79. Keller RP, Altermatt, HJ, Donatsch P, Zihlmann H, Laissue JA, Hiestand PC. Pharmacologic interactions between the resistance-modifying cyclosporine SDZ PSC 833 and etoposide (VP 16-213) enhance in vivo cytostatic activity and toxicity. Int J Cancer 1992; 51: 433-8.

80. Peng Yong W, Desai AA, Innocenti F, Ramirez J, Shepard D, Kobayashi K, et al. Pharmacokinetic modulation of oral etoposide by ketoconazole in patients with advanced cancer. Cancer Chemother Pharmacol 2007; 60 811-9.

81. Harvey VJ, Slevin ML, Joel SP, Johnston A, Wrigley PFM. The effect of food and concurent chemotherapy on the bioavailability of oral etoposide. $\mathrm{Br} J$ Cancer 1985; 52: 363-7.

82. Reif S, Nicolson MC, Bisset D, Reid M, Kloft C, Jaehde U, et al. Effects of grapefruit juice intake on etoposide bioavailability. Eur J Clin Pharmacol 2002; 58: 491-4

83. Najar IA, Sharma SC, Singh GD, Koul S, Gupta PN, Javed S, et al. Involvment of P-glycoprotein and CYP3A4 in the enhancement of etoposide bioavailability by a piperine analogue. Chem Biol Interact 2011; 190: 84-90.

84. Lee CK, Ki SH, Choi JS. Effects of oral curcumin on the pharmacokinetics of intravenous and oral etoposide in rats: possible role of intestinal CYP3A and P-gp inhibition by curcumin. Biopharm Drug Dispos 2011; 32: 245-51. 
85. Rodman JH, Murry DJ, Madden T, Santana VM. Altered etoposide pharmacokinetics and time to engraftment in pediatric patients undergoing autologous bone marrow transplantation. J Clin Oncol 1994; 12: 2390-7.

86. Shah JC, Chen JR, Chow D. Preformulation study of etoposide: Identification of physicochemical characteristics responsible for the low and erratic oral bioavailability of etoposide. Pharm Res 1989; 6: 408-12.

87. Slevin ML. The clinical pharmacology of etoposide. Cancer 1991; 67: 319-29.

88. Joel SP, Clark PI, Slevin ML. Stability of the i.v. and oral formulations of etoposide in solution. Cancer Chemother Pharmacol 1995; 37: 117-24.

89. Arai R, Kodema N, Tsuruta M, Furuse K, Nishiwaki Y, Nemoto E, et al. A cooperative phase II study of NK 171 (etoposide) in small cell lung cancer - comparison of results between the intravenous administration and the oral administration. Lung Cancer 1986; 2: 110.

90. Furuse K. [A Phase II study of etoposide (NK171) in small cell lung cancer - comparison of results between intravenous administration and oral administration]. [Japanese]. Gan To Kagaku Ryoho 1985; 12: 2352-7.

91. Ohno S, Sugama $Y$, Sugiyama $Y$, Kitamura S. Comparison of chronic oral and intravenous etoposide administration in combination with cisplatin for the treatment of small cell lung cancer. [Abstract]. Lung Cancer 1991; 7(Suppl 1): 118

92. Miller AA, Herndon JE 2nd, Hollis DR, Ellerton J, Langleben A, Richards F 2 nd, et al. Schedule dependency of 21-day oral versus 3-day intravenous etoposide in combination with intravenous cisplatin in extensive-stage small-cell lung cancer: A randomized phase III study of the cancer and leukemia group B. J Clin Oncol 1995; 13: 1871-9.

93. Girling DJ. Comparison of oral etoposide and standard intravenous multidrug chemotherapy for small-cell lung cancer: a stopped multicentre randomised trial. Medical Research Council Lung Cancer Working Party. Lancet 1996; 348: 563-6.

94. Souhami RL, Spiro SG, Rudd RM, Ruiz de Elvira MC, James LE, Gower NH, et al. Five-day oral etoposide treatment for advanced small-cell lung cancer: randomized comparison with intravenous chemotherapy. I Natl Cancer Inst 1997, 89: 577-80.

95. Sparreboom A, de Jonge MJA, Verweij J. The use of oral cytotoxic and cytostatic drugs in cancer treatment. Eur J Cancer 2002; 38: 18-22.

96. Zhang T, Chen J, Zhang Y, Shen Q, Pan W. Characterization and evaluation of nanostructured lipid carrier as a vehicle for oral delivery of etoposide. Eur J Pharm Sci 2011; 43: 174-97.

97. Wu Z, Guo D, Deng L, Zhang Y, Yang Q, Chen J. Preparation and evaluation of a self-emulsifying drug delivery sistem of etoposide-phospholipid complex. Drug Dev Ind Pharm 2011; 37: 103-12.

98. Zhang F, Koh GY, Hollingsworth J, Russo PS, Stout RW, Liu Z. Reformulation of etoposide with solubility-enhancing rubusoside. Int J Pharm 2012; 434: 453-9.

99. Mo R, Xiao Y, Sun M, Zhang C, Ping Q. Enhancing effect of N-octyl-O-sulfate chitosan on etoposide absorption. Int J Pharm 2011; 409: 38-45.

100. Chabot GG, Armand JP, Terret C, de Forni M, Abigerges D, Winograd B, et al. Etoposide bioavailability after oral administration of the prodrug etoposide phosphate in cancer patients during a phase I study. J Clin Oncol 1996; 14: 2020-30.

101. 96 Sessa C, Zucchetti M, Cerny T, Pagani O, Cavalli F, De Fusco M, et al. Phase I clinical and harmacokinetic study of oral etoposide phosphate. J Clin Oncol 1995; 13: 200-9.

102. de Jong RS, Mulder NH, Uges DRA, Kaul S, Winograd B, Sleijfer DTh, et al. Randomized comparison of etoposide pharmacokinetics after oral etoposide phosphate and oral etoposide. Br J Cancer 1997; 75: 1660-6.

103. Mathijssen RHN, de Jong FA, Loos WJ, van der Bol JM, Verweij J, Sparreboom A. Flat-fixed dosing versus body surface area-based dosing of anticancer drugs in adults: does it make a difference? Oncologist 2007; 12: $913-23$

104. Lowis SP, Price L, Pearson ADJ, Newell DR, Cole M. A study of the feasibility and accuracy of pharmacokinetically guided etoposide dosing in children. Br J Cancer 1998; 77: 2318-23.
105. El-Yazigi A, Ezzat A, Berry J, Raines DA, Yusuf A, Al-Rawithi S, et al. Optimization of oral etoposide dosage in elderly patients with non-Hodgkin's lymphoma using the fraction of dose absorbed measured for each patient. J Clin Pharmacol 2000; 40: 153-60.

106. Holz JB, Köppler H, Schmidt L, Fritsch HW, Pflüger KH, Jungclas H. Limited sampling models for reliable estimation of etoposide area under the curve. Eur J Cancer 1995; 31A: 1794-8.

107. Gentili D, Zucchetti M, Torri V, Sessa C, de Jong J, Cavalli F, et al. A limited sampling model for the pharmacokinetics of etoposide given orally. Cancer Chemother Pharmacol 1993; 32: 482-6.

108. Millward MJ, Newell DR, Yuen K, Matthews JP, Balmanno K, Charlton CJ, et al. Pharmacokinetics and pharmacodynamics of prolonged oral etoposide in women with metastatic breast cancer. Cancer Chemother Pharmacol 1995; 37: 161-7.

109. Minami H, Ando Y, Sakai S, Shimokata K. Clinical and pharmacologic analysis of hyperfractionated daily oral etoposide. J Clin Oncol 1995; 13: 191-9.

110. Tranchand B, Amsellem C, Chatelut E, Freyer G, lliadis A, Ligneau B, et al. A limited-sampling strategy for estimation of etoposide pharmacokinetics in cancer patients. Cancer Chemother Pharmacol 1999; 43: 316-22.

111. Palle J, Frost BM, Gustafsson G, Hellebostad M, Kanerva J, Liliemark E. Etoposide pharmacokinetics in children treated for acute myeloid leukaemia. Anticancer Drugs 2006; 17: 1087-94.

112. Lowis SP, Pearson ADJ, Newell DR, Cole M. Etoposide pharmacokinetics: the development and prospective validation of a dosing equation. Cancer Res 1993; 53: 4881-9.

113. Ando Y, Minami H, Saka H, Ando M, Sakai S, Shimokata K. Therapeutic drug monitoring in 21-day oral etoposide treatment for lung cancer. Jpn J Cancer Res 1996; 87: 856-61.

114. Lowis SP, Price L, Pearson ADJ, Newell DR, Cole M. A study of the feasibility and accuracy of pharmacokinetically guided etoposide dosing in children. Br J Cancer 1998; 77: 2318-23.

115. Aarons L. Population pharmacokinetics: theory and practice. $\mathrm{Br} J$ Clin Pharmacol 1991; 31: 669-70.

116. Nguyen I, Chatelut E, Chevreau C, Tranchand B, Lochon I, Bachaud JM, et al. Population pharmacokinetics of total and unbound etoposide. Cancer Chemother Pharmacol 1998; 41: 125-32.

117. Toffoli G, Corona G, Sorio R, Robieux I, Basso B, Colussi AM, et al. Population pharmacokinetics and pharmacodynamics of oral etoposide. $J$ Clin Pharmacol 2001; 52: 511-9.

118. Ciccolini J, Monjanel-Mouterde S, Bun SS, Blanc C, Duffaud F, Favre R, et al. Population pharmacokientics of etoposide: application to therapeutic drug monitoring. Ther Drug Monit 2002; 24: 709-14.

119. Nebert DW. Polymorphisms in drug-metabolizing enzymes: what is their clinical relevance and why do they exist? Am J Hum Genet 1997; 60: 265-71.

120. Miller AA, Tolley EA, Niell HB, Griffin JP, Mauer AM. Pharmacodynamics of prolonged oral etoposide in patients with advanced non-small-cell lung cancer. J Clin Oncol 1993; 11: 1179-88.

121. Miller AA, Tolley EA, Niell HB. Therapeutic drug monitoring of 21-day oral etoposide in patients with advanced non-small cell lung cancer. Clin Cancer Res 1998; 4: 1705-10. 